\title{
Adaptability and Growth of a Fast-Growing Neolamarckia cadamba (Roxb.) Bosser Clone in the South Subtropical Region of China
}

\author{
Run-Peng Wei ${ }^{*}{ }^{\oplus}$, Weibao $\mathrm{Zhu}^{2}$ \\ ${ }^{1}$ Weirptech Bioresources Limited, Hong Kong, China \\ ${ }^{2}$ Tianhai Agricultural Development Co. Ltd., Yunfu, China \\ Email: *runpengwei@yahoo.com.hk
}

How to cite this paper: Wei, R.-P., \& Zhu, W. B. (2019). Adaptability and Growth of a Fast-Growing Neolamarckia cadamba (Roxb.) Bosser Clone in the South Subtropical Region of China. Open Journal of Forestry, 9, 419-438.

https://doi.org/10.4236/ojf.2019.94024

Received: August 26, 2019

Accepted: October 28, 2019

Published: October 31, 2019

Copyright $\odot 2019$ by author(s) and Scientific Research Publishing Inc. This work is licensed under the Creative Commons Attribution International License (CC BY 4.0).

http://creativecommons.org/licenses/by/4.0/

\begin{abstract}
The present study investigated the adaptability and growth of a fast-growing clone (BN1) of N. cadamba planted as short-rotation plantation species in the south subtropical region of China, using 17 sampled sites representing different environments, planting models and ages, and local weather station temperature records. BN1's growth characteristics were further compared with the most productive eucalypts planted nearby. The survival of BN1 seedlings raised and transplanted with tissue-culture micro-cuttings was $>94.0 \%$ in the $1^{\text {st }}$ year, and the percentage of the effective trees with diameter at breast height $\left(D_{b h}\right) \geq 8 \mathrm{~cm}$ was $>71.0 \%$ over 30 -month old. Most of the sampled sites and trees were susceptible to low-temperature or frost injury in the $1^{\text {st }}$ winter, with average damage index $\left(\bar{I}_{d}\right)$ ranging from 0.1 to 2.6. Some sites/trees were infected by caterpillar or borer pests, but the damage was neglectable. The injured trees quickly sprouted out leading shoots and recovered their growing vigor from low temperature or insect damage. Temperature factors were closely related to $\bar{I}_{d} \quad(P<0.01)$, which could be used to identify suitable sites for planting BN1. Ten sampled sites were located in the marginal areas of the suitable climate zones, and planted BN1 trees might be lightly affected by frost or historical low temperature; seven sites had historically low temperature $\left(\leq 0^{\circ} \mathrm{C}\right)$ with risk of significant frost damage on $\mathrm{BN} 1$ trees; one site (No. 9) was not suitable with frequent and heavy cold damage $\left(\bar{I}_{d}=2.6\right)$. BN1 grew extremely fast, with average diameter at breast height $\left(\bar{D}_{b h}\right)$ ranging from $14.5-20.3 \mathrm{~cm}$ and average tree height $\left(\bar{H}_{t}\right)$ from 12.3 $16.0 \mathrm{~m}$ at 54-month old, and $\bar{D}_{b h}$ from $17.8-22.7 \mathrm{~cm}$ and $\bar{H}_{t}$ from 14.4 $15.9 \mathrm{~m}$ at 66-month old, over different sites/soils and planting models. Peak for both $\bar{D}_{b h}$ and $\bar{H}_{t}$ appeared in the $2^{\text {nd }}$ year, but after 6-year old for av-
\end{abstract}


erage individual tree volume $\left(\bar{V}_{i}\right)$. BN1 was faster in $\bar{D}_{b h}$ at most sites but slower in $\bar{H}_{t}$ at all sites than eucalypts compared. Some sampled sites of BN1 performed similarly as or obviously better than most productive eucalypts in stock volume $\left(V_{s}\right)$. With properly planting density, tending and rotation, BN1 could be expected to outperform fast-growing eucalypts in terms of $\bar{D}_{b h}, \bar{V}_{i}$ and $V_{s}$, and to produce all diameter grades of timbers if the rotation age is extended beyond 8 to 9 years. Discussion was also given to potential silvicultural models, risks and limitations of planting BN1 and other superior N. cadamba varieties.

\section{Keywords}

N. cadamba, BN1, Adaptability, Survival, Growth

\section{Introduction}

Development of fast-growing and high-yield tree plantation is often expected to bring in two aspects of positive consequences: direct mass production of wood or objective products and indirect protection of natural forests. Many national or regional practices in the past half century proved that this was the most direct and effective way to meet the market demand on woods or wood products (FSA, 2013; Colodette et al., 2014; DAFF, 2015; FAO, 2015; Lee-Jones, 2016). It was also one of the most effective ways to protect ecological environments by converting wood supplies from natural forests to tree plantations (FSA, 2013; Mead, 2013; DAFF, 2015; Hashim et al., 2015; Lee-Jones, 2016). These dual roles are particularly important for China, a country with fast economic growth, impoverished forest resources, huge market demand on woods, and increasing need on protection of natural environments. In the past two decades, commercial tree plantations expanded quickly in China, such as eucalypts (Eucalyptus) in the south and poplars (Populus) in the central and north. For these fast-growing and high yield tree plantations, however, many unwanted issues and concerns were raised while huge wood production and well economic return were achieved (Hua et al., 2016). One of the main concerns was the low diversity associated with commercial plantation, including narrow genetic diversity, single species and simple plantation ecosystem and relevant issues over vast geographic and climatic regions (Wei, 2002; Hua et al., 2016). One of the main causes was that for certain planting regions, there was no similar or better fast-growing species or varieties available for planters to choose (FAO, 2001).

Kadam (Neolamarckia cadamba (Roxb.) Bosser, synonyms: Anthocephalus cadamba (Roxb.) Miq., A. chinensis (Lamk.) A. Rich. ex Walp.) is one of the most famous fast-growing tree species, naturally distributed in the tropical and sub-tropic regions of the south China, southeast Asia and Pacific (Jøker, 2000; Zheng, 2004; Chong et al., 2009; Orwa et al., 2009; Bijalwan et al., 2014). Due to its fast-growing characteristics, kadam has widely been introduced to regions with 
similar climates, including central and south America and Africa (Orwa et al., 2009). Based on few early planting and experimental reports, kadam's growth may be similar to or outperform other widely planted fast-growing tree species such as eucalypts, acacias (Acacia) and pines (Pinus) under similar climates (Guhathakurtha \& Banerjee, 1970; Chen, 1993; FAO, 2001; Bijalwan et al., 2014; Zhang et al., 2016), and poplars or willows under different climates. Therefore, it may be a good alternative or supplementary species for suitable regions to increase the productivity as well as species diversity of tree plantation ecosystem. However, there was less effort made to explore its potential as fast-growing and high-yield species in tree plantation development (Zou, 1977; Xu, 1979; Chen, 1993; Seo, 2013; Bijalwan et al., 2014), and there was no report about its scale and successful planting. This paper investigated the adaptability and growth of a fast-growing kadam clone (BN1) planted over a wide south-subtropical region in the south China.

\section{Materials and Methods}

\subsection{Planting Materials}

Few commercial kadam seedlots collected from Indonesia were brought into Guangzhou, China in early 1960s. Seedlings were raised and planted in several parks, gardens or arboretums. Although the origins of these early introduced seedlots were not recorded (unknown), the planted seedlings/trees grew well and started to flower and fruit normally from around the $4^{\text {th }}$ year. From their $4^{\text {th }}$ - or $5^{\text {th }}$-generation offspring retained, we selected superior plus trees with high growth productivity and good morphology (straight tree trunk, small branches, narrow crown, wide angle etc.). Subsequently, we tested the technologies of tissue culture propagation, planting, fertilization, etc., for these selected and cloned trees. In the present study, a superior clone (BN1 or NB1) was investigated, which was propagated by combining indoor tissue culture propagation (Lin et al., 2009; Deng et al., 2012; Kavitha et al., 2012) and nursery transplantation, and was exemplarily planted under multiple locations (with different site/soil conditions) and planting models in the south subtropical China (Figure 1; Table 1).

\subsection{Planting Sites and Models}

Well hardened tissue-culture seedlings around 150-day old were out-planted at different locations, land sites/soils and/or years. Types of the land sites covered farmlands, hills, gardens, and roadsides with loam soil, yellow earth, red earth, litho earth or alluvium; planting models included patch, row (belt) and scattering. Planting sites were burned and cleared before digging holes and planting. The size of planting hole was $50 \mathrm{~cm} \times 50 \mathrm{~cm} \times 40 \mathrm{~cm}$. Basal fertilizer of $1.25 \mathrm{~kg}$ dry chicken manure mixed with $0.25 \mathrm{~kg}$ compound fertilizer ( $\mathrm{N}: \mathrm{P}: \mathrm{K}=15: 15: 15)$ per cutting was applied to planting holes before topsoil was turned back and BN1 seedlings were planted. After planted, weeding and application of compound fertilizer ( $\mathrm{N}: \mathrm{P}: \mathrm{K}=15: 15: 15,0.5 \mathrm{~kg}$ per tree) were applied to hilly sites in the spring of the $2^{\text {nd }}$ year, but not to other sites and/or in other tree ages. 


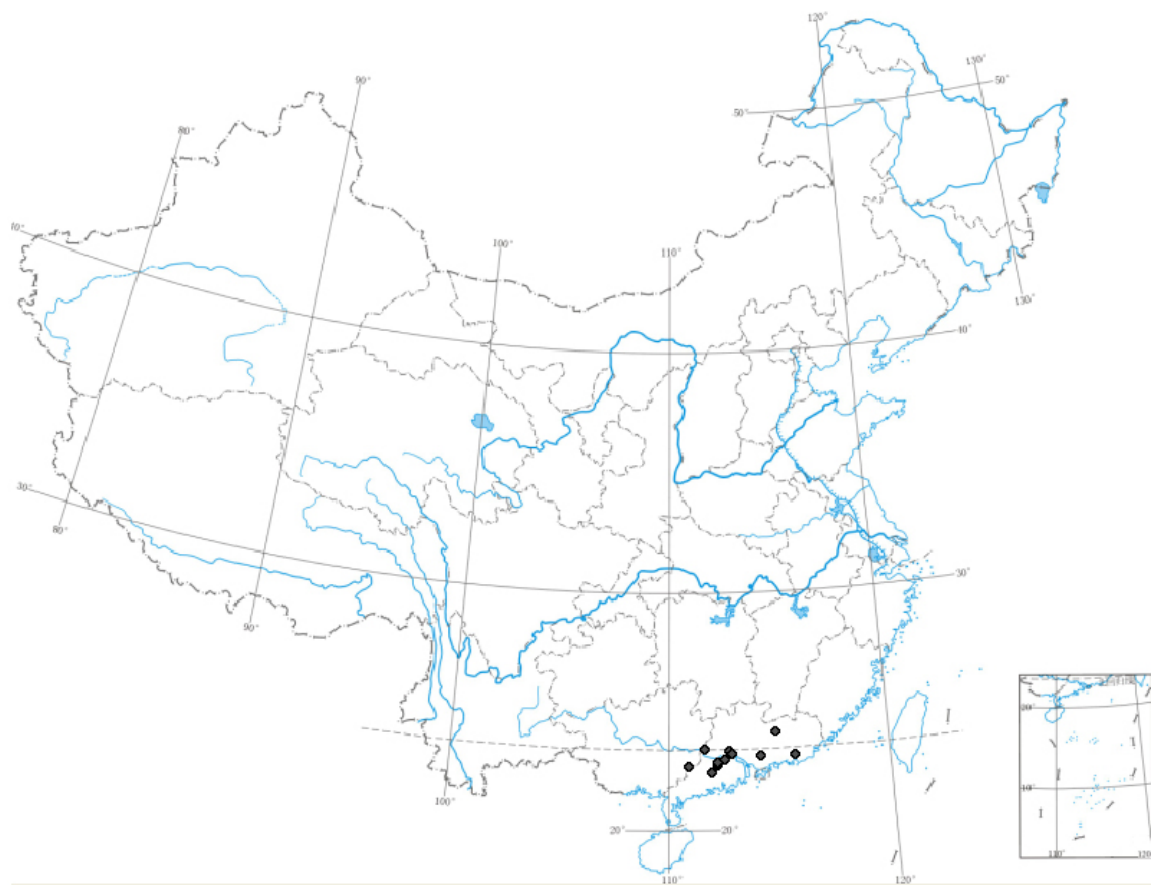

Figure 1. Geographic distribution of 17 planting sites/sampling pots (solid dot) of BN1 clone.

\subsection{Sampling Plots}

Seventeen sampling plots/sites, referred to as such jointly by sampled squares, belts and scattering trees, were established to represent different sites, planting models and ages of trees (Table 1), and their geographic locations were mapped in Figure 1. Table 1 listed: 1) site type, soil type, planting model and spacing or density; 2) geographic location (latitude, longitude and altitude); 3) first winter's lowest temperature $\left(\mathrm{T}_{\mathrm{L} 1}\right)$ after planted recorded at the nearest weather station; 4 ) extreme low temperature $\left(\mathrm{T}_{\mathrm{L} 8}\right)$, averaged annual mean temperature $\left(\mathrm{T}_{\mathrm{M}}\right)$ and averaged growing-degree days (GDD, mean annual cumulated temperature over $5^{\circ} \mathrm{C}$ ) from 2011 to 2018 (2345 Weather Web, 2019), 5) extreme historic low temperature $\left.\left(\mathrm{T}_{\mathrm{L}}\right) ; 6\right)$ average frost-free days $(\mathrm{FFD})$ and mean annual rainfall $\left.\left(\mathrm{P}_{\mathrm{M}}\right) ; 7\right)$ tree age (month). Besides, the growth data collected from the best fast-growing eucalypts (Eucalyptus) planted near few sampling sites and/or under similar planting conditions were utilized as the benchmark to study kadam.

\subsection{Assessment Traits}

First, the low temperature or frost damage was subjectively assessed in March after the young trees (age $<12$ months) experienced the first winter weather. The damage index $\left(I_{d}\right)$ was recorded for each tree according to the following criteria (Table 2).

Second, survival or retained survival $\left(S_{r}\right)$ was investigated by simply counting the surviving and dead trees. Meanwhile, diameter at breast height $\left(D_{b h}\right)$ and tree height $\left(H_{t}\right)$ were measured for each surviving trees. $D_{b h}$ and $H_{t}$ were used as direct growth traits, while survival and low temperature damage index measured 
Table 1. Description of planting models, geographic locations and climate environments for sampled sites.

\begin{tabular}{|c|c|c|c|c|c|c|c|c|c|c|c|c|c|c|c|c|}
\hline \multirow[b]{2}{*}{$\begin{array}{l}\text { Plot } \\
\text { No }\end{array}$} & \multirow{2}{*}{ Location } & \multirow[b]{2}{*}{ Site type } & \multirow[b]{2}{*}{ Soil type } & \multirow{2}{*}{$\begin{array}{c}\text { Planting } \\
\text { model }\end{array}$} & \multirow{2}{*}{$\begin{array}{c}\text { Spacing } \\
(\mathrm{m})\end{array}$} & \multicolumn{3}{|c|}{ Geographic ordinate } & \multicolumn{7}{|c|}{ Climate condition } & \multirow{2}{*}{$\begin{array}{c}\text { Tree } \\
\text { age/ } \\
\text { month }\end{array}$} \\
\hline & & & & & & N Lat & E Long & $\mathrm{Alt} / \mathrm{m}$ & $\mathrm{T}_{\mathrm{L} 1} /{ }^{\circ} \mathrm{C}$ & $\mathrm{T}_{\mathrm{L} 8} /{ }^{\circ} \mathrm{C}$ & $\mathrm{T}_{\mathrm{L}} /{ }^{\circ} \mathrm{C}$ & $\mathrm{T}_{\mathrm{M}} /{ }^{\circ} \mathrm{C}$ & $\begin{array}{c}\mathrm{FFD} / \\
\mathrm{d}\end{array}$ & GDD & $\begin{array}{l}\mathrm{P}_{\mathrm{M}} / \\
\mathrm{mm}\end{array}$ & \\
\hline 1 & $\begin{array}{c}\text { CG, } \\
\text { Xinxing }\end{array}$ & $\begin{array}{l}\text { Nursery } \\
\text { roadside }\end{array}$ & $\begin{array}{l}\text { Loam } \\
\text { soil }\end{array}$ & $\begin{array}{l}\text { Single } \\
\text { row }\end{array}$ & 2.45 & $22^{\circ} 46^{\prime} 44^{\prime \prime}$ & $112^{\circ} 13^{\prime} 34^{\prime \prime}$ & 25.0 & 1 & 1 & 1 & 22.85 & 359 & 6520 & 1664 & 66 \\
\hline 2 & $\begin{array}{c}\text { CG, } \\
\text { Xinxing }\end{array}$ & $\begin{array}{l}\text { Field } \\
\text { ridge }\end{array}$ & $\begin{array}{l}\text { Loam } \\
\text { soil }\end{array}$ & $\begin{array}{l}\text { Two } \\
\text { rows }\end{array}$ & $2.63 \times 2.5$ & $22^{\circ} 46^{\prime} 43^{\prime \prime}$ & $112^{\circ} 13^{\prime} 31^{\prime \prime}$ & 23.5 & 1 & 1 & 1 & 22.85 & 359 & 6520 & 1664 & 66 \\
\hline 3 & $\begin{array}{c}\text { CG, } \\
\text { Xinxing }\end{array}$ & $\begin{array}{l}\text { Field } \\
\text { ridge }\end{array}$ & $\begin{array}{l}\text { Loam } \\
\text { soil }\end{array}$ & $\begin{array}{l}\text { Three } \\
\text { rows }\end{array}$ & $2.29 \times 2.5$ & $22^{\circ} 46^{\prime} 45^{\prime \prime}$ & $112^{\circ} 13^{\prime} 31^{\prime \prime}$ & 24.5 & 1 & 1 & 1 & 22.85 & 359 & 6520 & 1664 & 66 \\
\hline 4 & $\begin{array}{c}\text { CG, } \\
\text { Xinxing }\end{array}$ & Farmland & $\begin{array}{l}\text { Loam } \\
\text { soil }\end{array}$ & Block & $2.8 \times 3.0$ & $22^{\circ} 46^{\prime} 44^{\prime \prime}$ & $112^{\circ} 13^{\prime} 32^{\prime \prime}$ & 24.0 & 1 & 1 & 1 & 22.85 & 359 & 6520 & 1664 & 66 \\
\hline 5 & $\begin{array}{l}\text { YG, } \\
\text { Yunfu }\end{array}$ & Low hill & $\begin{array}{l}\text { Red } \\
\text { earth }\end{array}$ & Block & $2.3 \times 3.4$ & $22^{\circ} 51^{\prime} 16^{\prime \prime}$ & $112^{\circ} 12^{\prime} 44^{\prime \prime}$ & 35.0 & 1 & 1 & 1 & 22.70 & 350 & 6483 & 1528 & 54 \\
\hline 6 & $\begin{array}{l}\text { AT, } \\
\text { Yunfu }\end{array}$ & $\begin{array}{l}\text { Foothill } \\
\text { farmland }\end{array}$ & $\begin{array}{l}\text { Red } \\
\text { earth }\end{array}$ & Block & $3.0 \times 3.8$ & $22^{\circ} 53^{\prime} 18^{\prime \prime}$ & $112^{\circ} 12^{\prime} 44^{\prime \prime}$ & 53.5 & 1 & 1 & 1 & 22.70 & 350 & 6483 & 1528 & 54 \\
\hline 7 & $\begin{array}{c}\text { AT, } \\
\text { Yunfu }\end{array}$ & $\begin{array}{c}\text { Low } \\
\text { farmland }\end{array}$ & $\begin{array}{l}\text { Loam } \\
\text { soil }\end{array}$ & Block & $1.25 \times 1.3$ & $22^{\circ} 56^{\prime} 23^{\prime \prime}$ & $112^{\circ} 10^{\prime} 33^{\prime \prime}$ & 52.6 & 1 & 1 & 1 & 22.70 & 350 & 6483 & 1528 & 54 \\
\hline 8 & $\begin{array}{c}\text { JD, } \\
\text { Gaoyao }\end{array}$ & $\begin{array}{l}\text { Garden } \\
\text { planting }\end{array}$ & $\begin{array}{l}\text { Yellow } \\
\text { earth }\end{array}$ & Scattering & - & $23^{\circ} 02^{\prime} 59^{\prime \prime}$ & $112^{\circ} 32^{\prime} 05^{\prime \prime}$ & 12.0 & 3 & 3 & 3 & 23.14 & 360 & 6625 & 1648 & 16 \\
\hline 9 & $\begin{array}{c}\text { BG, } \\
\text { Fengkai }\end{array}$ & Low hill & $\begin{array}{l}\text { Yellow } \\
\text { earth }\end{array}$ & Block & $4.0 \times 4.0$ & $23^{\circ} 31^{\prime} 02^{\prime \prime}$ & $111^{\circ} 35^{\prime} 58^{\prime \prime}$ & 66.4 & 0 & -1 & -1 & 22.24 & 320 & 6298 & 1480 & 46 \\
\hline 10 & $\begin{array}{l}\text { LF, } \\
\text { Sihui }\end{array}$ & $\begin{array}{c}\text { Low } \\
\text { hill valley }\end{array}$ & $\begin{array}{l}\text { Red } \\
\text { earth }\end{array}$ & Block & $2.3 \times 2.2$ & $23^{\circ} 24^{\prime} 21^{\prime \prime}$ & $112^{\circ} 44^{\prime} 03^{\prime \prime}$ & 26.0 & 6 & 0 & 0 & 22.55 & 360 & 6409 & 1813 & 20 \\
\hline 11 & $\begin{array}{l}\text { LF, } \\
\text { Sihui }\end{array}$ & Low hill & $\begin{array}{l}\text { Red } \\
\text { earth }\end{array}$ & Block & $2.3 \times 2.2$ & $23^{\circ} 24^{\prime} 25^{\prime \prime}$ & $112^{\circ} 44^{\prime} 05^{\prime \prime}$ & 36.0 & 6 & 0 & 0 & 22.55 & 360 & 6409 & 1813 & 18 \\
\hline 12 & $\begin{array}{c}\text { CW, } \\
\text { Yangchun }\end{array}$ & $\begin{array}{c}\text { Flat } \\
\text { dryland }\end{array}$ & $\begin{array}{l}\text { Litho } \\
\text { earth }\end{array}$ & Block & $4.0 \times 4.0$ & $22^{\circ} 30^{\prime} 50^{\prime \prime}$ & $111^{\circ} 56^{\prime} 33^{\prime \prime}$ & 112.0 & 4 & 2 & 2 & 23.48 & 350 & 6752 & 2380 & 30 \\
\hline 13 & $\begin{array}{c}\text { DP, } \\
\text { Puning }\end{array}$ & $\begin{array}{l}\text { Garden } \\
\text { Planting }\end{array}$ & $\begin{array}{l}\text { Litho } \\
\text { earth }\end{array}$ & Scattering & - & $23^{\circ} 09^{\prime} 17^{\prime \prime}$ & $115^{\circ} 50^{\prime} 06^{\prime \prime}$ & 132.0 & 6 & 0 & 0 & 23.02 & 352 & 6583 & 2102 & 44 \\
\hline 14 & $\begin{array}{l}\text { ND, } \\
\text { Cengxi }\end{array}$ & Low hill & $\begin{array}{l}\text { Yellow } \\
\text { earth }\end{array}$ & Block & $4.0 \times 4.0$ & $22^{\circ} 48^{\prime} 49^{\prime \prime}$ & $110^{\circ} 53^{\prime} 10^{\prime \prime}$ & 250.0 & -1 & -1 & -1 & 22.63 & 334 & 6439 & 1450 & 6 \\
\hline 15 & $\begin{array}{c}\text { LB, } \\
\text { Sanshui }\end{array}$ & Riverbank & Loam & $\begin{array}{l}\text { Three } \\
\text { rows }\end{array}$ & $2.5 \times 2.5$ & $23^{\circ} 17^{\prime} 40^{\prime \prime}$ & $112^{\circ} 53^{\prime} 04^{\prime \prime}$ & 7.0 & 3 & 1 & -0.7 & 23.02 & 354 & 6584 & 1683 & 10 \\
\hline 16 & $\begin{array}{l}\text { LY, } \\
\text { Boluo }\end{array}$ & $\begin{array}{l}\text { River } \\
\text { beach }\end{array}$ & Alluvium & Block & $3.0 \times 3.0$ & $23^{\circ} 07^{\prime} 16^{\prime \prime}$ & $114^{\circ} 14^{\prime} 05^{\prime \prime}$ & 9.0 & 2 & 0 & -1.5 & 23.34 & 345 & 6698 & 1833 & 4 \\
\hline 17 & $\begin{array}{c}\text { ZX, } \\
\text { Dongyuan }\end{array}$ & $\begin{array}{l}\text { River } \\
\text { bank }\end{array}$ & $\begin{array}{l}\text { Litho } \\
\text { earth }\end{array}$ & Scattering & - & $24^{\circ} 08^{\prime} 01^{\prime \prime}$ & $114^{\circ} 55^{\prime} 19^{\prime \prime}$ & 148.0 & 2 & 0 & -4.5 & 22.69 & 340 & 6469 & 1567 & 12 \\
\hline
\end{tabular}

the adaptability of young kadam trees to site conditions (particularly to low winter temperature). By combining $D_{b h}$ and $H_{t}$ the following indirect traits were also evaluated: 1) ratio of tree height to diameter at breast height $\left(R_{h d}=H_{t}(\mathrm{~m}) / D_{b h}(\mathrm{~cm})\right)$ indicating feature of tree form (Wei et al., 2004; Mu et al., 2006; Zhang et al., 2006); 2) individual standing tree volume $\left(V_{p} \mathrm{~m}^{3}\right)$ and standing volume per hectare $\left(V_{s}, \mathrm{~m}^{3} / \mathrm{ha}\right)$ measuring the wood productivity of 
Table 2. Grading low temperature damage on young BN1 trees in the first winter after planted.

\begin{tabular}{ccl}
\hline Grade & $I_{d}$ & \multicolumn{1}{c}{ Description of damage characteristics } \\
\hline 1 & 0 & $\begin{array}{l}\text { No damage on growth or stem form } \\
\text { Minor damage on growth (tree height loss } \leq 10 \%) \text { or stem form likely with } \\
\text { slight scars }\end{array}$ \\
3 & 1 & $\begin{array}{l}\text { Medium damage on growth (tree height loss between } 10 \%-30 \%) \text { or stem } \\
\text { form with visible scars or slightly forking shoots }\end{array}$ \\
4 & 3 & $\begin{array}{l}\text { Heavy damage on growth (tree height loss between } 30 \%-60 \%) \text { or stem } \\
\text { form with severe scars or forking shoots (upper part) }\end{array}$ \\
5 & 4 & $\begin{array}{l}\text { Severe damage on growth (tree height loss between }>60 \%), \text { stem broken } \\
\text { and forking (lower part), or dead }\end{array}$ \\
\hline
\end{tabular}

trees or stands,

$$
V_{i}=0.0000369 D_{b h}^{2} H_{t} \quad \text { (Krisnawati et al., 2011), }
$$

and,

$$
V_{s}=N_{t} \bar{V}_{i},
$$

where, $N_{t}=$ effective tree number per hectare, and $\bar{V}_{i}=\sum_{1}^{N_{t}} V_{i} / N_{t}$, mean individual volume.

\subsection{Statistical Analysis}

Sigmaplot 2000 (SPSS Inc., 2000) was employed to do the following statistical analysis and draw the relevant figures: 1) calculation of means, estimate standard errors, maximum and minimum values of survival, low temperature damage index, diameter at breast height, tree height and individual tree volume for each sampling plot; 2) linear regression of low temperature damage index against the first winter's lowest temperature, mean annual temperature, frost-free day, and growing degree day or mean annual cumulated temperature over $5^{\circ} \mathrm{C}$, by using 11 sampling plots with the $1^{\text {st }}$ winter lowest temperature $\leq 2^{\circ} \mathrm{C} ; 3$ ) use of Logistic model (SPSS Inc., 2000) to fit the relationship of tree height and diameter at breast height with all $\mathrm{BN} 1$ trees measured (included some older trees early planted beyond the sampling plots), by referring to Krisnawati et al. (2011); 4) comparison of some BN1 plots with the standard plot or trees of eucalypt clones with highest wood yield in the south China.

\section{Results}

\subsection{Retained Survival and Low Temperature Damage Index}

Statistics of the retained survival, damage index, diameter at breast-height and tree height for 17 sampled plots were presented in Table 3. All sampled plots had $>94.0 \%$ survival at the end of the first year. For instance, the survival for plot 14 , representing hilly condition, was $94.4 \%$. After two and half years (30 months), all sampled plots except for plot 7 had effective retained survival $\left(D_{b h} \geq\right.$ 
Table 3. Mean, standard error ( $S E$ ), maximum (Max) and/or minimum (Min) values in the adaptive and growth traits of different sampling plots.

\begin{tabular}{|c|c|c|c|c|c|c|c|c|c|c|c|c|c|c|c|c|c|c|}
\hline \multicolumn{2}{|c|}{ Plot No. } & 1 & 2 & 3 & 4 & 5 & 6 & 7 & 8 & 9 & 10 & 11 & 12 & 13 & 14 & 15 & 16 & 17 \\
\hline \multicolumn{2}{|c|}{ No of trees assessed } & 23 & 14 & 23 & 58 & 33 & 40 & 24 & 16 & 24 & 24 & 24 & 35 & 8 & 24 & 32 & 40 & 10 \\
\hline \multirow{2}{*}{$S_{r}$} & Mean/\% & 78.3 & 71.4 & 78.3 & 85.0 & 87.0 & 85.7 & 48.0 & 100 & 92.9 & 96.0 & 95.0 & 94.3 & 100 & 94.4 & 96.7 & 97.5 & 100 \\
\hline & $S E( \pm)$ & 8.79 & 12.53 & 8.79 & 4.65 & 7.18 & 6.0 & 7.14 & 0 & 7.14 & 3.45 & 3.50 & 3.98 & 0 & 5.56 & 3.39 & 2.50 & 0 \\
\hline \multirow{4}{*}{$I_{d}$} & Mean & 0.1 & 0.4 & 0.3 & 0.8 & 1.2 & 0.5 & 0.9 & 0 & 2.6 & 0 & 0 & 0 & 0 & 1.9 & 0 & 0 & 0 \\
\hline & $S E( \pm)$ & 0.11 & 0.22 & 0.17 & 0.19 & 0.25 & 0.15 & 0.23 & 0 & 0.24 & 0 & 0 & 0 & 0 & .23 & 0 & 0 & 0 \\
\hline & $\operatorname{Max}$ & 2 & 2 & 3 & 4 & 4 & 3 & 3 & 0 & 4 & 0 & 0 & 0 & 0 & 4 & 0 & 0 & 0 \\
\hline & Min & 0 & 0 & 0 & 0 & 0 & 0 & 0 & 0 & 2 & 0 & 0 & 0 & 0 & 1 & 0 & 0 & 0 \\
\hline \multirow{4}{*}{$D_{b h}$} & Mean $/ \mathrm{cm}$ & 22.7 & 22.7 & 20.1 & 17.8 & 14.5 & 20.3 & 14.8 & 7.4 & 9.4 & 10.5 & 6.6 & 13.0 & 18.7 & 4.5 & 2.50 & - & 3.8 \\
\hline & $S E( \pm)$ & 1.26 & 1.30 & 1.09 & 0.69 & 0.58 & 0.65 & 0.97 & 0.43 & 0.30 & 0.38 & 0.43 & 0.37 & 0.80 & 0.39 & 0.19 & - & 0.43 \\
\hline & $\mathrm{Max} / \mathrm{cm}$ & 29.2 & 29.9 & 31.4 & 29.9 & 20.2 & 29.9 & 28.2 & 9.2 & 12.3 & 12.3 & 9.2 & 17.1 & 22.8 & 6.5 & 5.4 & - & 6.5 \\
\hline & $\mathrm{Min} / \mathrm{cm}$ & 8.8 & 11.7 & 10.8 & 10.1 & 9.7 & 10.4 & 9.4 & 4.9 & 8.3 & 7.8 & 4.6 & 8.8 & 15.8 & 3.3 & 0.9 & - & 2.2 \\
\hline \multirow{4}{*}{$H_{t}$} & Mean/m & 15.9 & 14.4 & 15.6 & 15.0 & 13.9 & 16.0 & 12.3 & 5.4 & 7.7 & 7.5 & 5.6 & 9.6 & 10.5 & 3.1 & 2.0 & - & 2.7 \\
\hline & $S E( \pm)$ & 0.64 & 0.58 & 0.61 & 0.43 & 0.42 & 0.36 & 0.42 & 0.31 & 0.50 & 0.15 & 0.25 & 0.37 & 0.63 & 0.17 & 0.12 & - & 0.21 \\
\hline & $\mathrm{Max} / \mathrm{m}$ & 18.5 & 17.5 & 20.3 & 20.6 & 17.5 & 19.3 & 16.4 & 6.6 & 8.8 & 8.2 & 7.0 & 10.9 & 12.9 & 4.0 & 3.6 & - & 4.1 \\
\hline & $\mathrm{Min} / \mathrm{m}$ & 8.5 & 10.5 & 10.2 & 7.5 & 8.3 & 7.7 & 8.5 & 3.6 & 5.9 & 5.5 & 4.3 & 8.5 & 7.8 & 2.4 & 0.6 & - & 2.0 \\
\hline \multirow{4}{*}{$V_{i}$} & Mean $/ \mathrm{m}^{3}$ & 0.332 & 0.296 & 0.264 & 0.206 & 0.119 & 0.263 & 0.111 & 0.012 & 0.031 & 0.031 & 0.010 & 0.058 & 0.141 & - & - & - & - \\
\hline & $S E( \pm)$ & 0.0373 & 0.0374 & 0.0337 & 0.0208 & 0.0117 & 0.1218 & 0.0178 & 0.0017 & 0.0052 & 0.0023 & 0.0017 & 0.0075 & 0.0195 & - & - & - & - \\
\hline & $\operatorname{Max} / \mathrm{m}^{3}$ & 0.580 & 0.554 & 0.739 & 0.653 & 0.248 & 0.596 & 0.369 & 0.021 & 0.046 & 0.044 & 0.021 & 0.086 & 0.247 & - & - & - & - \\
\hline & $\operatorname{Min} / \mathrm{m}^{3}$ & 0.024 & 0.054 & 0.044 & 0.037 & 0.029 & 0.031 & 0.029 & 0.003 & 0.016 & 0.016 & 0.004 & 0.037 & 0.072 & - & - & - & - \\
\hline
\end{tabular}

Note: 1) All living trees at 20-month and younger ages and plot 9 (unsuitable site, see next subsection) were included in statistics, but only effective trees with $D_{b h} \geq 8 \mathrm{~cm}$ for all other plots of trees $\geq 30$-month age; 2) At plot 14, the survival and growth were measured in November but cold damage (occurred in February) index was assessed in the coming April.

$8 \mathrm{~cm}$ ) higher than $71.0 \%$. The low effective survival for plot 7 (48.0\%) was mainly due to the artificial and natural thinning of small trees under high initial planting density (6150 trees/ha) (Singh \& Lal, 1982). Even though with low effective survival, the number of its retained effective trees was still high (2835 trees/ha). Relatively low standard errors for all plots' retained survival implied stable survivals over sites in general.

In the beginning of 2014 and 2016, when the lowest temperature went down to $-1^{\circ} \mathrm{C}-2^{\circ} \mathrm{C}$ at most locations (2345 Weather Web, 2019), low temperature or frost damage appeared on most 1-yr old young trees (planted in spring or summer, $<12$ months). Near all these sampled sites, fast-growing eucalypt clone DH3229 were planted in large scale every year but the young trees $(<12$-month) did not suffer from low temperature or frost damage, well indicating that BN1 or fast-growing kadam trees were more sensitive to low temperature or frost (Zou, 1977; Xu, 1979; Jøker, 2000) although there might be a difference among kadam provenances or varieties (Huang et al., 2016). In general, slightly affected trees 
$\left(I_{d} \leq 2.0\right)$ well recovered their growth or stem form under site conditions with rich moisture and nutrition. In few sampled BN1 plots, however, some severely damaged individuals would not recover their stem form or shoot vigor since then. Young BN1 trees sampled from sites with the lowest temperature $\geq 3^{\circ} \mathrm{C}$ in the first winter had no damage symptom (Table 3).

First winter extreme low temperature, mean annual temperature, growing degree day and frost-free days were closely related (Hong et al., 2005), which all significantly affected low temperature or frost damage (Figure 2) $(r=-0.81, P=$ $0.002 ; r=-0.76, P=0.006 ; r=-0.71, P=0.013 ; r=-0.78, P=0.005)$. Among these climate factors, the first winter extreme low temperature had closest relationship with low temperature or frost damage, successively followed by growing degree day (GDD), mean annual temperature $\left(T_{M}\right)$, and frost free period (FFD). However, all temperature factors had no effect on tree survival, and tender shoots and leaves of $\mathrm{BN} 1$ trees were sensitive to extreme low temperature or frost in winter (Zou, 1977; Xu, 1979; Huang et al., 2016). For example, site/plot 14 had a relatively long frost period ( 21 days/year in average), and the most young BN1 trees significantly suffered from the historically low temperature in early $2016\left(\bar{I}_{d}=1.9\right.$ ) (Liu, 2016). Site/plot 9 was located in the north, on the northwest slope of an inland hill with frost each year (Table 1) (2345 Weather Web, 2019), where BN1 trees were severely damaged from low temperature damage each year, most of shoots and leaves died or injured, and more than half of all trees' current-year height growth died back. Although having relatively high survival and growth, the trees obviously had poor trunk form with high damage index $\left(\bar{I}_{d}=2.6\right)$ in comparing with other sites.
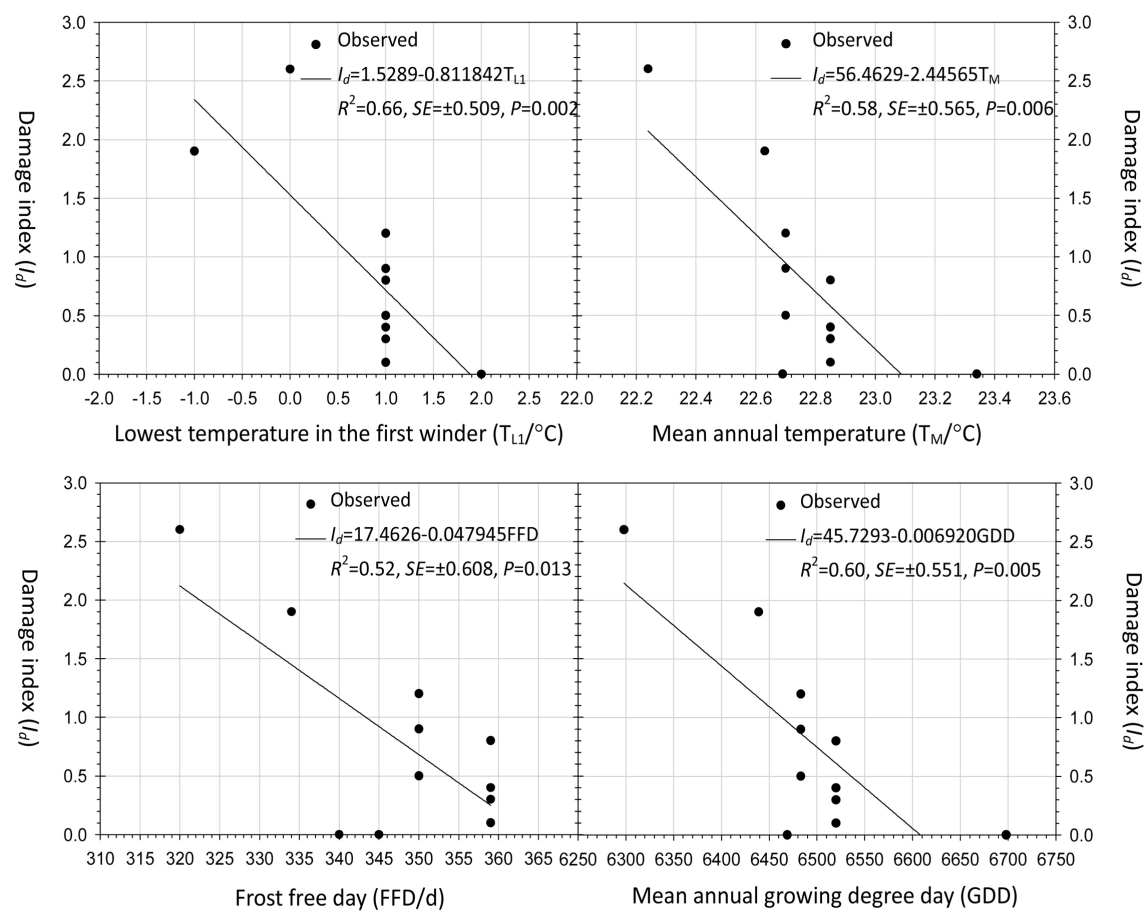

Figure 2. Linear relationship of BN1 young tree damage index against 4 climate factors. 
Young BN1 trees are subjective to low temperature damage in the first winter, but their low-temperature resistant capacity was slightly improved as trees became older ( $\geq 18$ months old). Besides survival and low temperature damage index investigated, some caterpillars (defoliators) were observed on BN1 leaves or borers on upper parts of few trees older than 30 months. However, the damage frequency and level were very low, not affecting the general growth and quality of trees sampled.

\subsection{Diameter and Tree Height}

In general, BN1 trees grew very fast (Table 3). Average diameter at breast height $\left(\bar{D}_{b h}\right)$ of BN1 trees reached $13.0 \mathrm{~cm}$ at 30-month old (plot 12), and $18.7 \mathrm{~cm}$ at 44-month old (plot 13); the correspondent average tree height $\left(\bar{H}_{t}\right)$ were $9.6 \mathrm{~m}$ and $10.5 \mathrm{~m}$ respectively. $\bar{D}_{b h}$ ranged from $14.5-20.3 \mathrm{~cm}$ and $\bar{H}_{t}$ from $12.3-$ $16.0 \mathrm{~m}$ (plots 5 - 7) at 54-month old. The largest two dominant trees from the stand with plot 7 sampled had $D_{b h} \geq 32 \mathrm{~cm}$ (Figure 3), and $H_{t}$ of $17.8 \mathrm{~m} . \bar{D}_{b h}$ at 66-month (6-year old) ranged from $17.8-22.7 \mathrm{~cm}$ and $\bar{H}_{t}$ from $14.4-15.9 \mathrm{~m}$ (plots 1 - 4). Trees from all other sites/plots sampled with younger ages also exhibited fast-growing feature (Table 3). Tree growth at site 9 was relatively slow, due to frequent low winter temperature damage, which could be classified as unsuitable for commercial planting. Estimate standard errors of $D_{b h}$ and $H_{t}$ for all plots sampled were relatively small and uniform, implying the stability in growth of BN1 trees over different sites and planting models (Table 1 and Table 3).

By referring to Krisnawati et al. (2011), all available growth data collected from $\mathrm{BN} 1$ trees (most from sampled plots listed in Table 1) were used to regress

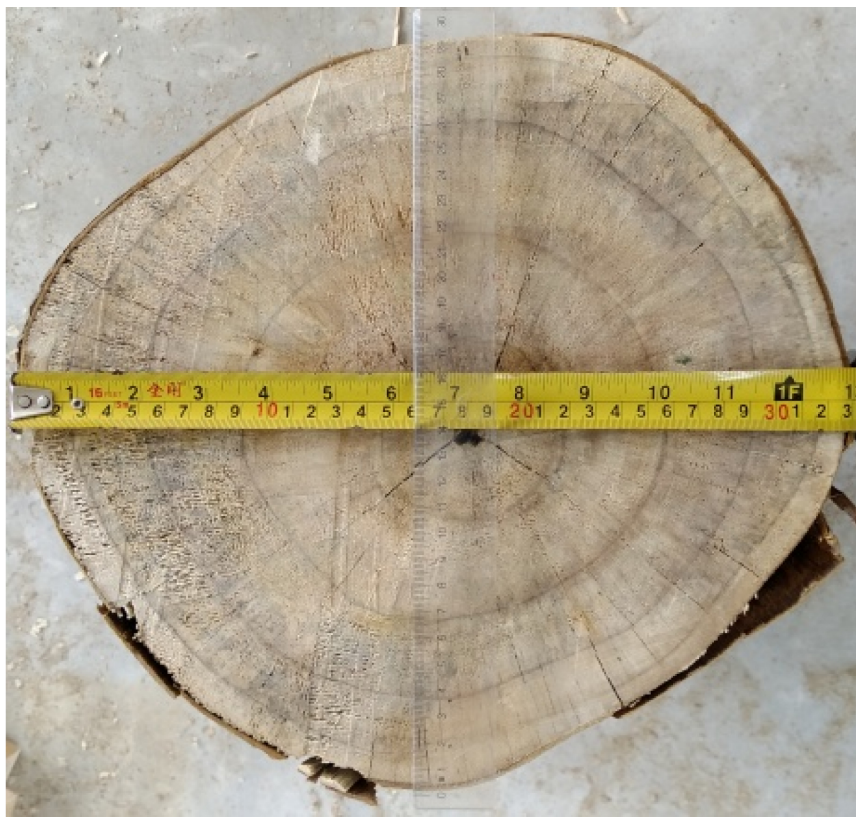

Figure 3. Cross section of a 54-month old dominant tree at $1.3 \mathrm{~m}$ height-showing ring growth. 
tree height $\left(H_{t}\right)$ against diameter at breast height $\left(D_{b h}\right)$. The original data and fitting curve were plotted in Figure 4. Both regression models of the present study and Krisnawati et al. (2011) and all their model parameters were extremely significant $(P<0.0001)$. The present regression model better fitted the relationship of $H_{t}$ and $D_{b h}$ by considering its sample size $(690)$, fitness $\left(R^{2}=0.93\right)$ and estimate standard error $(S E= \pm 1.747)$. Both regressions had similar profile of the relationship, but represented the average performance of trees at different ages, sites and planting models for different genetic varieties. The regressed height of BN1 trees was obviously higher than that by using the model obtained by Krisnawati et al. (2011), possibly indicating the genetic superiority of BN1 in height growth.

\subsection{Growth Trend over Ages}

Figure 5 exhibited the growth trends over ages of average diameter at breast height $\left(\bar{D}_{b h}\right)$, tree height $\left(\bar{H}_{t}\right)$ and individual volume $\left(\bar{V}_{i}\right)$ under two planting models, i.e., single row planting along roadside (plot 1 ) and patch planting on farmland (plot 4). $\bar{D}_{b h}$ was $4.1 \mathrm{~cm}$ for both plots at 6 months old, and increased to 11.3 and $10.3 \mathrm{~cm}$ (the annual increments of 7.2 and $6.2 \mathrm{~cm}$ ), respectively, for plots 1 and 4 at 18 months old. In the $3^{\text {rd }}$ year, trees still grew fast for both plots with $\bar{D}_{b h}$ reaching 16.8 and $12.9 \mathrm{~cm}$ (the annual increments of 5.5 and $2.6 \mathrm{~cm}$ ), respectively, but their growth rate markedly slowed down. Afterward, the annual increment for both plots further reduced, and ended up with 1.3 and $1.4 \mathrm{~cm}$, respectively, in the $5^{\text {th }}$ year. The cross section of tree trunk at $1.3 \mathrm{~m}$ height from the second largest dominant tree sampled from site/plot 7 clearly exhibited the growth trend over the first 5 years with growth peak in the $2^{\text {nd }}$ year (Figure 3 ). $\bar{H}_{t}$ had similar growth trend as $\bar{D}_{b h}$ although both measure scales were different (Figure 5).

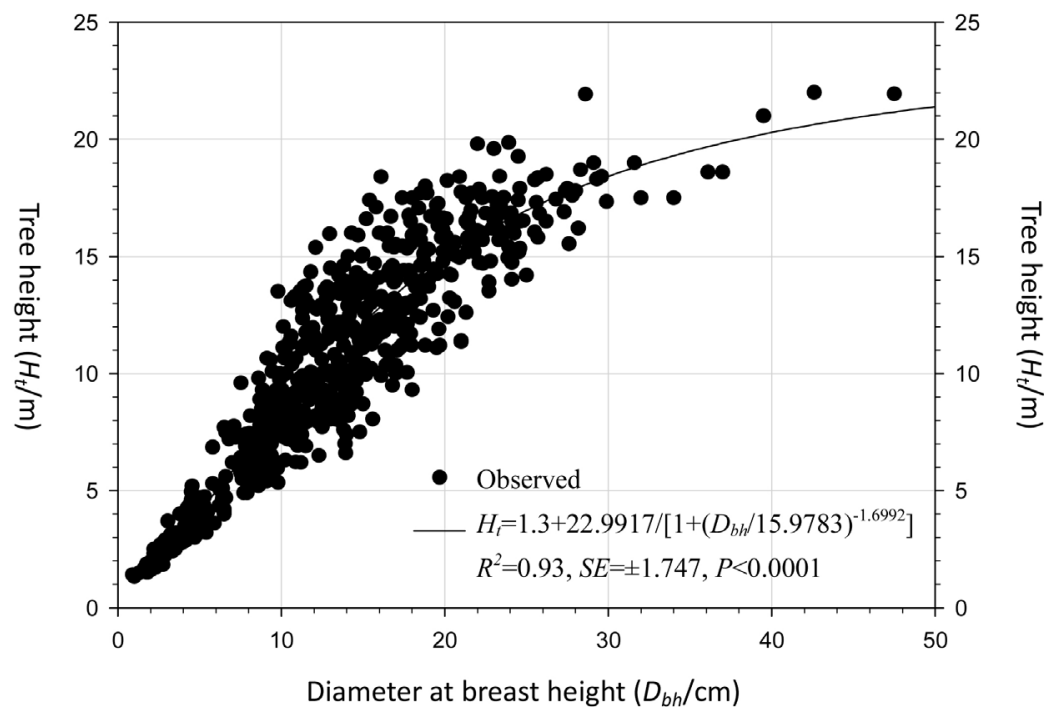

Figure 4. Regression of tree height against diameter at breast height $\left(D_{b h}\right)$ for BN1 trees. 


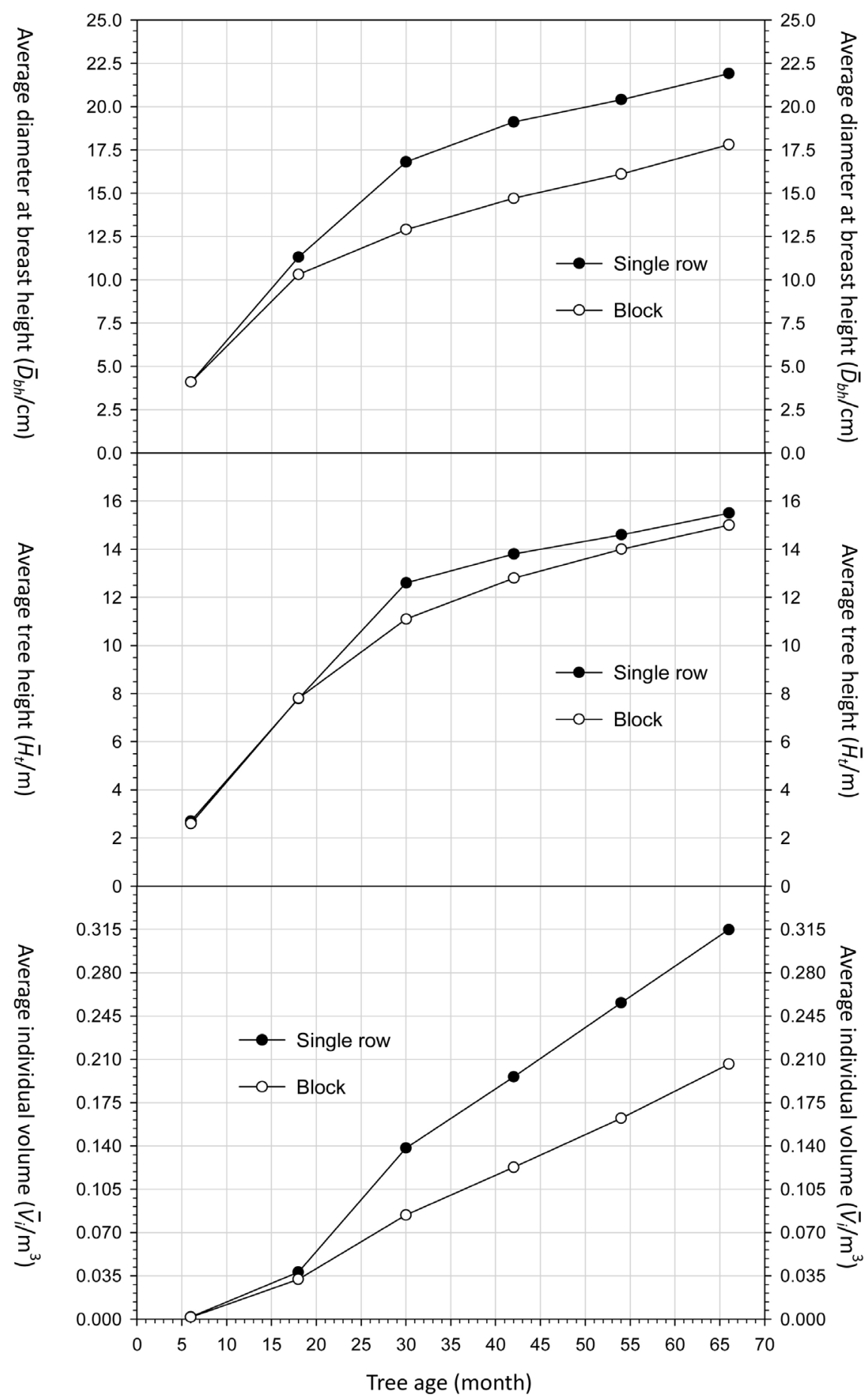

Figure 5. Average growth in $D_{b h}, H_{t}$ and $V_{i}$ over age of BN1 trees planted in single row (plot 1) and block (plot 4).

Till the end of the $1^{\text {st }}$ year (6-month old), trees from single-row (plot 1) and patch planting (plot 4) grew similarly, as all trees were young, without competition for growing space. As trees grew further, both $\bar{D}_{b h}$ and $\bar{H}_{t}$ under two planting models started to diverge. By the end of the $2^{\text {nd }}$ year (18 months), plot 1 obviously yielded larger $\bar{D}_{b h}$ than plot $4(11.3 \mathrm{~cm}$ vs 10.3$)$, but both had the 
same $\bar{H}_{t}$ of $7.8 \mathrm{~m}$. This divergence resulted from competition for growing space. In the summer of the $2^{\text {nd }}$ year, trees in plot 4 had crowns well closed, and the diameter growth started to be suppressed, but height growth was still not affected. Subsequently, both plots further diverged in growth with difference of 3.9 $\mathrm{cm}$ in $\bar{D}_{b h}$ and $1.5 \mathrm{~m}$ in $\bar{H}_{t}$ at the end of $3^{\text {rd }}$ year (30 months old), and $4.3 \mathrm{~cm}$ in $\bar{D}_{b h}$ and $1.5 \mathrm{~m}$ in $\bar{H}_{t}$ at the end of the $5^{\text {th }}$ year (54 months old). The result showed that trees in plot 4 had harsh competition for space, with individual growth negatively affected.

\subsection{Comparison with High-Yield Eucalypt Clones}

Some sites/plots from roadside (plot 1), farmlands (plots 4, 6 and 7), upland (plot 12) and hilly site (plot 5) representing different site or soil conditions and planting densities were compared with fast-growing eucalypts commonly planted nearby or sampled within the same or similar climate zones (Table 4). Average growth of BN1 trees in plot 1 was compared with that of 3 fast growing eucalypt clones, i.e. DH3229 (E. urophylla $\times$ E. grandis), JY66 (E. wetaransis $\times$ camaldulensis) and IP2 (E. grandis $\times$ E. urophylla), planted along roadside nearby (single row, SRP) with tree distance of $1.5 \mathrm{~m}$, at 6, 18, 30 and 42 months old. Data from a multi-age standard plot (MSP) of DH3229 planted at a hilly site, which yielded $180.8 \mathrm{~m}^{3} /$ ha at 66-month old and well represented the best production of fast-growing trees in south China, was used to compare with $\mathrm{BN} 1$ of sampled plots of 30, 54 and 66 months old (Table 4).

It was showed from Table 3 and Table 4 that all BN1 sites/plots, except for plot 9 , had $\bar{D}_{b h}$ growth obviously higher than fast-growing eucalypts, regardless of planting density (similar, low or high), site type (farmland, dry land or

Table 4. Comparison in growth between BN1 and high yield eucalypts.

\begin{tabular}{|c|c|c|c|c|c|c|c|c|c|c|c|c|}
\hline \multicolumn{2}{|c|}{ Age/month } & \multirow{2}{*}{$\begin{array}{l}6 \\
1\end{array}$} & \multirow{2}{*}{$\begin{array}{c}18 \\
1\end{array}$} & \multirow{2}{*}{$\begin{array}{c}30 \\
1\end{array}$} & \multirow{2}{*}{$\begin{array}{c}42 \\
1\end{array}$} & \multicolumn{2}{|c|}{30} & \multicolumn{4}{|c|}{54} & \multirow{2}{*}{$\begin{array}{c}66 \\
4\end{array}$} \\
\hline \multirow{6}{*}{$\mathrm{BN} 1$} & Plot & & & & & 4 & 12 & 4 & 5 & 6 & 7 & \\
\hline & trees/ha & - & - & - & - & 1071 & 590 & 1012 & 1113 & 752 & 2835 & 997 \\
\hline & $\bar{D}_{b h} / \mathrm{cm}$ & 4.1 & 11.3 & 16.8 & 19.1 & 14.1 & 13.0 & 16.3 & 14.5 & 20.3 & 14.8 & 17.8 \\
\hline & $\bar{H}_{t} / \mathrm{m}$ & 2.7 & 7.8 & 12.6 & 13.8 & 11.8 & 9.4 & 14.0 & 13.9 & 16.0 & 12.3 & 15.0 \\
\hline & $\bar{V}_{i} / \mathrm{m}^{3}$ & - & 0.037 & 0.138 & 0.196 & 0.095 & 0.058 & 0.164 & 0.119 & 0.263 & 0.111 & 0.206 \\
\hline & $V_{s} / \mathrm{m}^{3} / \mathrm{ha}$ & - & - & - & - & 101.7 & 34.1 & 166.1 & 132.3 & 197.4 & 313.4 & 205.4 \\
\hline \multirow{6}{*}{ Eucalypts } & Control & \multicolumn{4}{|c|}{$\mathrm{SRP}^{*}$} & \multicolumn{2}{|c|}{$\mathrm{MSP}^{\star}$} & \multicolumn{4}{|c|}{$\mathrm{MSP}^{\star}$} & $\mathrm{MSP}^{*}$ \\
\hline & Trees/ha & - & - & - & - & \multicolumn{2}{|c|}{1245} & \multicolumn{4}{|c|}{1155} & 1140 \\
\hline & $\bar{D}_{b h} / \mathrm{cm}$ & 2.9 & 9.0 & 12.3 & 14.0 & \multicolumn{2}{|c|}{11.8} & \multicolumn{4}{|c|}{14.5} & 15.1 \\
\hline & $\bar{H}_{t} / \mathrm{m}$ & 3.5 & 10.6 & 14.4 & 16.0 & \multicolumn{2}{|c|}{14.7} & \multicolumn{4}{|c|}{20.2} & 21.7 \\
\hline & $\overline{V_{i}} / \mathrm{m}^{3}$ & - & 0.036 & 0.090 & 0.120 & \multicolumn{2}{|c|}{0.080} & \multicolumn{4}{|c|}{0.148} & 0.158 \\
\hline & $V_{s} / \mathrm{m}^{3} / \mathrm{ha}$ & - & - & - & - & \multicolumn{2}{|c|}{98.9} & \multicolumn{4}{|c|}{170.6} & 180.6 \\
\hline
\end{tabular}

*1) SRP = a single row plot of 3 eucalypt clones (DH3229, JY66 and IP2) planted near Plot 1 of BN1;2) MSP = a multi-age standard plot of eucalypt clone DH3229. 
hills) and soil type. In contrast, fast-growing eucalypts always had higher height growth than BN1. These growth features of $D_{b h}$ and $H_{t}$ also reflected in the ratio of $H_{t}$ and $D_{b h}\left(R_{h d}\right) . R_{h d}$ was $0.81(S E= \pm 0.006)$ for BN1 in the present study while fast-growing eucalypts usually had $R_{h d}$ higher than 1.20 (Wei et al., 2004; Mu et al., 2006; Zhang et al., 2006).

Individual tree volume was functional to $D_{b h}$ and $H_{t}$. Therefore, difference between two kinds of fast-growing species/varieties depends on their difference in $D_{b h}$ and $H_{t}$. Without competition for growing space, two kinds of trees did not show obvious difference in individual tree volume $\left(V_{i}\right)$, at least so before the end of the $2^{\text {nd }}$ year or 18 months old (Table 3 and Table 4). As trees became older, the difference in individual volume and wood yield changed much, due to the effects of growing space or planting density and site/soil conditions (Singh \& Lal, 1982; Chen, 1993; Zhang et al., 2016). For example, BN1's individual volume in plot 4 was obviously higher than eucalypts, but both had similar wood yield. BN1 in plots 5 and 12 had average individual volume and wood yield markedly lower than eucalypts compared.

\section{Discussion}

\subsection{Adaptability}

All sampled sites/plots showed that tissue cultured cuttings of kadam clone (BN1) easily survived after planted, retained high rate of survival or effective trees, and grew fast with relatively uniform trees. Except for trees at sites/plots 9 and 14, all trees at other sites grew vigorously with slight or no damage from the first winter lower temperature. Even although suffering severe damage from the first winter low temperature, trees at sites/plots 9 and 14 had high planting or retained survival, and recovered fast-growing characteristic to certain level each year (Table 3). Nevertheless, severe low temperature damage led to relatively low growth rate with poor tree form, and thus low economic value. Therefore, BN1 was not suitable to this kind of sites for commercial planting.

From its natural distribution, kadam is adaptive to climates of tropical, south subtropical and some central subtropical regions, where could be the proper zones for planting fast-growing BN1 (Zou, 1977). Extreme low temperature factors such as $\mathrm{T}_{\mathrm{L} 1}, \mathrm{~T}_{\mathrm{L} 8}$ or $\mathrm{T}_{\mathrm{LH}}$, mean annual temperature $\left(\mathrm{T}_{\mathrm{M}}\right.$ ), frost-free days (FFD) and growing-degree day (GDD) could effectively be used to measure the climatic adaptability of sites (Hong et al., 2005) and risk for commercially planting BN1 (Figure 2; Table 1). For no cold damage, $\mathrm{T}_{\mathrm{LH}}, \mathrm{T}_{\mathrm{M}}$, FFD and GDD must be $\geq$ $1.9^{\circ} \mathrm{C}, 23.08^{\circ} \mathrm{C}, 365$ days (no frost) and 6608 , respectively. Few sites in the present study would meet these criteria (Table 1 ). A realistic practice was probably to accept certain level of low temperature damage (e.g. $\bar{I}_{d} \leq 1$ ). The low limits of $\mathrm{T}_{\mathrm{LH}}, \mathrm{T}_{\mathrm{M}}, \mathrm{FFD}$ and GDD then became $0.7^{\circ} \mathrm{C}, 22.68^{\circ} \mathrm{C}, 343$ days and 6470 , respectively. They are probably the appropriate demarcations, which could independently or jointly be used to judge the suitability of a site for planting BN1. For example, use of $T_{L 8}$ or $T_{L H}$ alone resulted in the same output: sites 9, 10, 11, 
$13,14,16$ and 17 were not suitable while others were located in the north margins of suitable regions, more or less subject to risk of slight frost damage.

According to some early studies, kadam was subject to damage of some pests, mainly including defoliators (caterpillars) such as Diaphania glauculalis Guenée and Cyclidia orciferaria Walder, and borers such as Acalolepta cervina Hope and Dihammus cervinus (Guo, 1982; Huang \& Pei, 1982; Nair, 2000; Zhao et al., 2008; Chung et al., 2009; Ma et al., 2015). Pests affect Kadam's tree growth, trunk straightness, and wood quality. In the worst situation, pest may eat up all leaves and tender shoots, leading to stand failure (Guo, 1982; Zhao et al., 2008). In the present study, minor pest damages were observed, but did not affect the tree growth. There was no obvious pests on BN1 probably due to the first and small-scale planting ( $<10$ ha for each location) of kadam at all sampling sites and their surroundings, or BN1's potential pest resistance. However, further research is needed to reveal its actual adaptability to insects.

The sampled sites/plots in the present study covered low hills or lower slope of mountains, dryland, farmland, footpath of fields, roadside, garden etc. (Table 1). Basically, all these sites had high heats, rainfall and deep soil with relatively rich nutrients, which are necessary for fast-growing and high yield trees such as kadam and eucalypts (Table 3) (Xu, 1979; Chen, 1993). To obtain high growth productivity, BN1 should be planted on flat lands, slow slopes, abandoned farmlands, foothills or low mountains. Although kadam is well adaptive to rainfall varying from 200 to $1500 \mathrm{~mm}$ (Jøker, 2000), rich soil moisture and good drainage in raining weathers are indispensable for its high productivity. Normally, tropical and south subtropical regions in China have rich rainfall for fast-growing trees, and waterlogged issue associated with flat or lowlands and valleys in raining seasons may be considered as main rainfall factors to impede the growth of BN1 and other kadam clones in a way.

\subsection{Fast-Growing Property}

It was showed from all sampled sites that BN1 had the excellent features of fast-growing (Guhathakurtha \& Banerjee, 1970; Zou, 1977; Chen, 1993; Su et al., 2007; Seo, 2013; Bijalwan et al., 2014; Zhang et al., 2016). In the end of the first year, the average diameter at breast height $\left(\bar{D}_{b h}\right)$ and tree height $\left(\bar{H}_{t}\right)$ of young BN1 trees reached $4.5 \mathrm{~cm}$ and $3.1 \mathrm{~m}$, respectively, at a hilly site (6-month, plot 14), and $5.4 \mathrm{~cm}$ and $3.9 \mathrm{~m}$, respectively, in a garden (8.5-month, plot 13). Trees of plot 9 had poorest growth and trunk form that resulted from annually frost damage, but still exhibited the fast-growing feature of BN1. Nevertheless, this site or similarities should not be considered as suitable for commercial planting.

BN1 grew extremely fast in early years, particularly at the second year, with the annual increment of $\bar{D}_{b h}$ as large as more than $9 \mathrm{~cm}$. Growth peak for both $\bar{D}_{b h}$ and $\bar{H}_{t}$ appeared at the $2^{\text {nd }}$ year (Figure 3 and Figure 5). According to the 6-yr (66-month old) growth trend of sampled plots (plots 1 and 4) as well as the dominant tree from plot 7 (Figure 3), the annual increment in volume of in- 
dividual tree would reach peak after 6-yr old, and its difference with mean annual increment in volume of individual tree increased for the first four years and gradually decreased from $5^{\text {th }}$ year. It was roughly predicted that optimal harvest time fell between 8- and 9-year (YFI, 1975; Chen, 1993; Soerianegara \& Lemmens, 1993; Hashim et al., 2015), and $D_{b h}, H_{t}$ and $V_{i}$ of the dominant tree could then reach $40 \mathrm{~cm}, 21 \mathrm{~m}$ and $1.1 \mathrm{~m}^{3}$, respectively. Obviously, BN1 clone has a high growth potential in comparison with fast-growing eucalypt, and seedling kadam trees reported early (Guhathakurtha \& Banerjee, 1970; Chen, 1993; Su et al., 2007; Bijalwan et al., 2014).

The volume $\left(V_{i}\right)$ of a standing individual tree depends on its $D_{b h}$ and $H_{t}$ and $V_{i}$ and the number $\left(N_{t}\right)$ of the effective trees decide the total stocking volume or yield (Equations (1) and (2)). Comparison with best fast-growing eucalypts (Table 4 ) indicated that with certain site/soil conditions and proper planting model and density, BN1 could well outperform fast-growing and high-yield eucalypt varieties currently widely planted (Singh \& Lal, 1982; FAO, 2001; Bijalwan et al., 2014; Zhang et al., 2016). This conclusion could be extended to the final harvest. The divergence in $R_{h d}\left(H_{t} / D_{b h}\right)$ between $\mathrm{BN} 1$ and eucalypts (0.81 vs. 1.20$)$ revealed the growth characteristics in $D_{b h}$ and $H_{t}$ of both species, including species or genetic effect as well as roles of cultivation or growing conditions (Wei et al., 2004).

BN1 had significant low $R_{h d}$ value than fast-growing eucalypts (Wei et al., 2004; $\mathrm{Mu}$ et al., 2006; Zhang et al., 2006). Obviously, its tree form as well as wood production in plantations could be improved by increasing $R_{h d}$ or relatively reducing diameter through proper adjustment of tree stockings (density) and application of cultivation technology (Chen, 1993; Zhang et al., 2016). In future improvement of kadam, on the other hand, BN1 could be used as breeding material (mother or father tree) to purposely be crossed with other parents with high $R_{d h}$, to breed superior clones or varieties with better characteristics (fast growing, high $R_{h d}$ or good tree form).

\subsection{Potential Silviculture Models}

Based on its growth trend over ages (Table 3 and Table 4; Figure 3 and Figure 5), BN1 could produce logs of different sizes (large, medium and small) at relatively short rotation. A proper cultivation model should be adopted according to a planter's choice and market conditions (Chen, 1993; Ren \& Zou, 2004; Seo, 2013; Hashim et al., 2015). Based on our findings, 3 types of cultivation models depending on planting density and thinning are recommended for consideration in development of kadam plantation. First, low planting density (405 - 675 trees/ha) without thinning mainly aims at large diameter logs $\left(\bar{D}_{b h}>25 \mathrm{~cm}\right)$ harvested at age of $8-9$ year. Second, medium planting density (675 to 1005 trees/ha) with a thinning imposed (375 - 450 dominant trees retained per ha) at around 5-year old leads to a combination of large, medium and small logs from final clear-cut at 8 - 9 year. Last, high planting density (1050 to 1350 trees/ha) 
without thinning, similar to fast-growing and high-yield eucalypts, is clearly cut at age of $6-7$ year, producing logs of small and medium size. If trees with large and medium size are more profitable later on, the last model could easily be converted to the second by thinning trees at 4 - 5 year old (retaining around 450 dominant trees per ha) and delaying clear-cut to 8 - 9 year old.

As a superior variety, $\mathrm{BN} 1$ is characterized with large leaves, sparsely small branches, and tree crowns of well light permeability, which is considered as a good tree species to intercrop or under-plant with other plants (Bijalwan et al., 2014). A potential cultivation model is to adopt low planting density with wide rows, relatively narrow tree distance, and no thinning, and to interplant herbs, upland crops, green feedstock, etc., for the first 2 - 4 years (Bijalwan et al., 2014; Lubis, 2014). It would increase the efficiency of land use and the total planting income, and benefit the tree growth and protection. This model mainly produces logs of large and medium size, and inter-planted plants, with less woods of small size. BN1 is also suitable for planting along roadsides, and in gardens (Jøker, 2000). As a roadside species, a relatively long harvest rotation without thinning must be considered. Therefore, a low density should be used, e.g. $>3 \mathrm{~m}$ tree distance for roadside planting. By the end of rotation, high proportion of large logs could be harvested.

\subsection{Significance of Planting BN1 in South China}

Maximization of economic efficiency in tree planting leads to low genetic and species diversity or high genetic uniformity associated with commercial plantation ecosystems. A typical case was planting of one or few eucalypt clones over a wide range of forestlands in south China (Wei, 2002; Hua et al., 2016). With high growth potential, BN1 and other superior kadam clones could be planted as an excellent alternative or supplementary species of eucalypts under suitable climates without or with slight frost, to increase wood productivity as well as plantation species diversity (Wei, 2002; Bijalwan et al., 2014; Hua et al., 2016).

Besides high growth yield, BN1 or other fast-growing kadam varieties may have better wood properties (FGTG, 1974; YFI, 1975; Soerianegara \& Lemmens, 1993; Jøker, 2000; Su et al., 2007) than fast-growing eucalypts with similar harvest rotation. This provides more options for defining BN1's cultivation models and wood products. For example, with similar or slightly longer rotation, BN1 could be planted to produce logs with only medium and small size, or all large, medium and small size (Table 3 ). Our preliminary testing showed that the wood densities at ages of 3 and 4 years were $0.381( \pm 0.0082) \mathrm{g} / \mathrm{cm}^{3}$ and $0.402( \pm 0.0061)$ $\mathrm{g} / \mathrm{cm}^{3}$, respectively. After felled down and sawn, logs or sawn timbers had no end split, bend and crook problems, and were easy to be processed into plank, board, batten, veneer, etc. (FGTG, 1974; YFI, 1975; Soerianegara \& Lemmens, 1993), while fast-growing eucalypt are limited to veneers and woodchip only. Therefore, BN1 may have higher (direct and indirect) economic value than eucalypts popularly planted. 


\subsection{Other Implications and Limits}

Low temperature damage and pests may become the main restrictions for planting BN1 and other fast-growing kadam clones (Figure 5; Zou, 1977; Guo, 1982; Huang \& Pei, 1982; Huang et al., 2016). Low temperature damage limits the suitable planting regions. However, large areas without or with slight frost in south China are still available for planting NB1. By replacing low-yield eucalypts and other tree species with fast-growing kadam in suitable regions, high plantation productivity and wood product diversity may be significantly obtained to meet the demand of local and nearby wood markets. At present, there is no mature or optimal planting model for BN1 and other fast-growing kadam varieties, lacking knowledge or technical information about planting density, spacing, rotation, fertilizing, etc. (Chen, 1993; Ren \& Zou, 2004; Seo, 2013). This is one of the main research directions for extending $\mathrm{BN} 1$ and other fast-growing kadam varieties in future.

\section{Acknowledgements}

We thank Professors Huoran Wang, Yuanzhao Hou and Yongqi Zheng for their valuable suggestions. The field assessment was completed with assistance of Jiwei Liu, Jian Liang, Qiaowen Wei and Chunming Zheng.

\section{Conflicts of Interest}

The authors declare no conflicts of interest regarding the publication of this paper.

\section{References}

2345 Weather Web (2019). History Observed Temperature: 1 Jan 2011 to 31 Mar 2019. http://tianqi.2345.com

Bijalwan, A., Dobriyal, M. J. R., \& Bhartiya, J. K. (2014). A Potential Fast Growing Tree for Agroforestry and Carbon Sequestration in India: Anthocephalus cadamba (Roxb.) Miq. American Journal of Agriculture and Forestry, 2, 296-301. https://doi.org/10.11648/j.ajaf.20140206.21

Chen, H. W. (1993). Investigation of Anthocephalus chinensis Growth under Different Planting Density at Mountainous Sites. Yunnan Forestry Science \& Technology, 4, 47-52.

Chong, K. Y., Tan, H. T. W., \& Corlett, R. T. (2009). A Checklist of the Total Vascular Plant Flora of Singapore: Native, Naturalised and Cultivated Species (273 p.). Singapore: Raffles Museum of Biodiversity Research, National University of Singapore.

Chung, A. Y. C., Ajik, M., Nilus, R., Hastie, A., Ong, R. C., \& Chey, V. K. (2009). New Records of Insects Associated with Laran (Neolamarckia cadamba) in Sabah. Sepilok Bullettin, 10, 45-63.

Colodette, J. L., Gomes, C. M., Gomes, F. J., \& Cabral, C. P. (2014). The Brazilian Wood Biomass Supply and Utilization Focusing on Eucalypt. Chemical \& Biological Technologies in Agriculture, 25, 1-8. https://doi.org/10.1186/s40538-014-0025-x

Deng, X. M., Zhan, Y. L., Zhang, Q., Huang, H., \& Chen X. Y. (2012). Study on Tissue Culture of Neolamarckia cadamba. Journal of South China Agricultural University, 33, 
216-224.

Department of Agriculture, Forestry and Fisheries (DAFF) (2015). Annual Report 2014/2015. Pretoria: Department of Agriculture, Forestry and Fisheries, Republic of South Africa.

FAO (2001). Mean Annual Volume Increment of Selected Industrial Forest Plantation Species. Forest Plantation Thematic Papers, Working Paper 1. Forest Resources Development Service, Forest Resources Division. Rome: FAO.

FAO (2015). Country Report: Brazil. Rome: Global Forest Resources Assessment, Country Report.

Fast-Growing Tree Group (FGTG) (1974). Preliminary Testing of Physical and Mechanic Properties of Anthocephalus chinensis Woods. Tropical Plant Research, 5, 11-13.

Forestry SA (FSA) (2013). Forestry Facts for the Year 2011/12. http://www.gov.za/about-sa/forestry

Guhathakurtha, P., \& Banerjee, A. K. (1970). The Rate of Growth of Some Species in North Bengal. Kolkata: West Bengal Forest Department.

Guo, B. (1982). Preliminary Investigation of Diaphania glauculalis (Guenee) in Xishuangbanna. Scientia Silvae Sinicae, 18, 103-106.

Hashim, M. N., MohdHazim, M. A., \& Syafinie, A. M. (2015). Strategic Forest Plantation Establishment in Malaysia for Future Product Development and Utilization. In Kuala Lumpur International Agriculture, Forestry and Plantation (pp. 1-16). Kuala Lumpur: KLIAFP.

Hong, Y., Nix, H. A., Hutchinson, M. F., \& Booth, T. H. (2005). Spatial Interpolation of Monthly Mean Climate Data for China. International Journal of Climatology, 25, 1369-1379. https://doi.org/10.1002/joc.1187

Hua, F. Y., Wang, X. Y., Zheng, X. L., Fisher, B., Wang, L., Zhu, J., Tang, Y., Yu, D. W., \& Wilcove, D. S. (2016). Opportunities for Biodiversity Gains under the World's Largest Reforestation Programme. Nature Communications, 7, Article No. 12717.

https://doi.org/10.1038/ncomms12717

Huang, H., Zhou, X. B., Ouyang, K. X., Li, J. C., Zeng, Z. J., \& Chen, X. Y. (2016). Comprehensive Evaluation of Cold Resistance of Neolamarckia cadamba. Journal of South China Agricultural University, 37, 82-88.

Huang, Y. Z., \& Pei, R. K. (1982). Dihammus cervinus Bates and Young Anthocephalus chinensis Trees. Yunnan Tropical Science \& Technology, 2, 41-44. https://doi.org/10.1080/02786828308958611

Jøker, D. (2000). Neolamarckia cadamba (Roxb.) Bosser (Anthocephalus chinensis (Lam.) A. Rich. ex Walp.). Seed Leaflet, No. 17, Humlebaek: Danida Forest Seed Centre.

Kavitha, M., Nair, R. R., Thilga, S., \& Ganesh, D., (2012). Standardization of Protocol for Explant Preparation and Plant Regeneration from Apical Bud and Nodal Explants of Anthocephalus cadamba. International Journal of Biological Technology, 3, 8-15.

Krisnawati, H., Kallio, M., \& Kanninen, M. (2011). Anthocephalus cadamba Miq.: Ecology, Silviculture and Productivity. Bogor: CIFOR.

Lee-Jones, D. (2016). New Zealand Forestry and Wood Products Report 2016. Gain Report No. NZ1606, Wellington: USDA Foreign Agricultural Service, Global Agricultural Information Network.

Lin, B. Z., Zhang, S. H., \& Lin, J. G. (2009). Study on Tissue Culture Technology in Fast Propagating Anthocephalus chineensis. China Tropical Agriculture, 3, 46-47.

Liu, C. Y. (2016). Chinese "Strongest Cold Wave" Ended on 25th, Touching down the 
Historical Lowest Temperature at 82 Weather Stations. China News Web, 26 Jan 2016.

Lubis, M. R. (2014). Turmeric (Curcuma domestica Val.) Plants under Agroforestry Stands Jabon (Anthocephalus cadamba Miq.). MSc Thesis, Bogor: IBP Bogor Agricultural University.

Ma, T., Liu, Z. T., Sun, C. H., Li, Y. Z., Chen, X. Y., \& Wen, X. J. (2015). Morphology and Bionomics of Diaphania glauculalis Guenée. Chinese Forest Pest \& Disease, 1, 5-8.

Mead, D. J. (2013). Sustainable Management of Pinus radiate Plantations. FAO Forestry Paper No. 170. Rome: FAO.

Mu, H. T., Wei, R.-P., \& Zhang, Y. W. (2006). Characteristics of Short-Rotation Eucalypt Individual Trees and Stands. Guangdong Forestry Science \& Technology, 22, 17-22.

Nair, K. S. S. (2000). Insect Pests and Diseases in Indonesian Forests: an Assessment of the Major Threats, Research Efforts and Literature (101 p.). Bogor: Center for International Forestry Research.

Orwa, C., Mutua, A., Kindt, R., Jamnadass, R., \& Anthony, S. (2009). Agroforestree Database: A Tree Reference and Selection Guide Version 4.0 (pp. 1-5). Nairobi: World Agroforestry Centre.

Ren, P. Y., \& Zou, S. Q. (2004). Silvicultural Technology of a Tropical Fast-Growing Tree (Anthocephalus chinensis). Practical Forestry Technology, 6, 6-8.

Seo, J. (2013). Silvicultural Practices and Growth of Jabon Tree (Anthocephalus cadamba Miq) in Community Forest, West Java, Indonesia (39 p.). Bogor: Bogor Agricultural University, Master Degree Thesis.

Singh, S. P., \& Lal, P. (1982). Effect of Different Spacing Treatments on Yield from Anthocephalus chinensis Plantations. Indian Forester, 108, 734-740.

Soerianegara, I., \& Lemmens, R. H. M. J. (1993). Plant Resources of South-East Asia No. 5(1). Timber Trees: Major Commercial Timbers. Wageningen: Pudoc Scientific Publishers.

SPSS Inc. (2000). Sigmaplot 2000-Programming Guide. Chicago: SPSS Inc.

Su, G. R., Yi, G. N., \& Yang, Q. (2007). A Study on Growth Character of Anthocephalus chinensis. Journal of Northwest Forestry University, 22, 49-52.

Wei, R.-P. (2002). Diversity-A Concern in Tree Plantation Development of China. In Collections of the National Conference of Forest Genetic and Breeding Section (p. 6). Nanchang: Chinese Association of Forestry.

Wei, R.-P., Zhang, Y., \& Mu, H. (2004). Effect of Planting Density on Performance of 20-Month-Old of Eucalypt Clones at a Trial in South China. In "Eucalyptus in Changing World" of IUFRO 2.08.03 WG Conference (pp. 346-348). Aveiro: RAIZ-Instituto de Investigação da Floresta e Papel.

Xu, M. (1979). Preliminary Report on Introduction of Anthocephalus chinensis. Fujian Tropical Crop Science \& Technology, 4, 13-14.

Yunnan Forest Institute (YFI) (1975). Study on Wood Properties and Uses of Anthocephalus chinensis from Yunnan. Yunnan Forestry Science \& Technology, 1, 1-4.

Zhang, L. C., Cao, J., Lin, J. H., Chen, X. Y., Peng, C. C., Deng, X, M., Lin, J. Y., \& Zeng S. C. (2016). Effects of Planting Density on the Growth and Stand Volume of Young Anthocephalus chinensis Plantation. Journal of South China Agricultural University, 37, 63-68.

Zhang, Y. W., Wei, R.-P., \& Mu, H. T. (2006). Role of Planting Density and Materials in Early Performance of a Short-Rotation Eucalypt Trial. Guangdong Forestry Science \& Technology, 22, 8-12. 
Zhao, L. F., Chen, P., \& Li, Q. (2008). Investigation on Major Insect Pests Damaging Six Valuable Broadleaved Tree Species in Tropical Areas of Yunnan Province. Journal of Southwest Forestry College, 28, 30-35.

Zheng, W. J. (2004). Sylva Sinica (Vol. 4, pp. 4594-4595). Beijing: China Forestry Publishing.

Zou, S. Q. (1977). Report on the Northward Introduction of Anthocephalus chinensis. Tropical Plant Research, 11, 26-35. 